\title{
BRILLIANT BLUE DYE REMOVAL IN FUNGICIDE SPRAYING
}

\author{
Doi:http://dx.doi.org/10.1590/1809-4430-Eng.Agric.v37n3p611-617/2017
}

\section{RONE B. OLIVEIRA ${ }^{1 *}$, RODRIGO Y. P. MARUBAYASHI ${ }^{2}$, MARCO A. GANDOLFO ${ }^{3}$, KARINA A. ALVES ${ }^{2}$}

1* Corresponding author. Universidade Estadual do Norte do Paraná - UENP/ Bandeirantes - PR, Brazil.

E-mail: rone@uenp.edu.br

\begin{abstract}
The method used for removal of brilliant blue dye may have an influence in interpreting the results of spraying deposition studies. The aim of this study was to assess the number of washings and water volumes for brilliant blue dye removal from soybean leaflets and glass slides in fungicide sprayings with and without adjuvants. A completely randomized experimental design was used in a $3 \times 3 \times 2 \times 4$ factorial scheme. The factors consisted of number of washings (1st, 2nd, and 3rd), water volume $(15,20$, and $30 \mathrm{~mL}$ ), target type (soybean leaflets and glass slides), and spray solutions (fungicide ProdutorBR ${ }^{\circledR} 0.5 \mathrm{~L} \mathrm{ha}^{-1}$ without and with the adjuvants vegetable oil Agr'óleo ${ }^{\circledR} 0.5 \% \mathrm{v} \mathrm{v} \mathrm{v}^{-1}$, mineral oil Nimbus ${ }^{\circledR} 0.5 \% \mathrm{v} \mathrm{v}^{-1}$, and surfactant Silwet ${ }^{\circledR} 0.04 \%$ $\mathrm{v} \mathrm{v}^{-1}$ ). Sprayings were carried out by using the nozzle model TT110015 at a pressure of $300 \mathrm{kPa}$ (medium droplets). After spraying, targets were washed and the amount of brilliant blue dye removed per target area was detected by spectrophotometry. Brilliant blue dye removal is higher in glass slide when compared to soybean leaflets. With a single washing, a higher difficulty in removing the brilliant blue dye was observed for fungicide with vegetable oil. Only the first washing and a water volume of $15 \mathrm{~mL}$ are insufficient for brilliant blue dye removal from soybean leaflets and glass slides.
\end{abstract}

KEYWORDS: Application technology, adjuvants, experimental methods.

\section{INTRODUCTION}

Distribution and quantity of product deposited on a target are important operational variables for an efficient phytosanitary treatment. In view of that, many studies have assessed different spraying techniques to determine which has the best application results. However, more methods that are efficient have been required to assess spraying performance on distribution and quantity of spray solution deposited on a given target (PALLADINI et al., 2005).

The evaluation of spray solution deposition on natural or artificial targets is the most representative method to understand several aspects related to spraying plant protection products. On the other side, costs may be a limiting factor in conducting studies by using active substances of plant protection products since complex analytical methods are required because of the diversity of molecules, sophisticated equipment, and people trained to carry out the analyses (MATUO, 1988). Thus, the use of markers is very important due to the ease of removal from leaves or collecting targets, in addition to presenting water solubility, low cost, and simple and precise methods for quantification (DE CERQUEIRA et al., 2012; MARCHI et al., 2005).

Brilliant blue dye is a non-toxic, water-soluble marker, easily extracted by washing or shaking with water, and often used to assess spray deposition from terrestrial and aerial agricultural applications (SILVA et al., 2014; CARVALHO et al., 2013; ZAIDAN et al., 2012). Nevertheless, this marker removal may vary with leaf morphological characteristics or target species used in quantitative studies of droplet spray deposition on intact natural targets (MARCHI et al., 2005). In addition, further marker-related studies should be carried out in order to avoid underestimating or

\footnotetext{
${ }^{2}$ Universidade Estadual de Londrina - UEL/ Londrina - PR, Brazil.

${ }^{3}$ Universidade Estadual do Norte do Paraná - UENP/ Bandeirantes - PR, Brazil.

Received in: 5-3-2016

Accepted in: 11-11-2016
} 
overestimating the deposition due to its retention on the target (CARVALHO et al., 2013).

Spraying deposition assessments are used to guide the development and improvement of techniques for the application of plant protection products using natural or artificial targets (REZENDE, 2011). However, different plant protection products present in spray solutions can increase or reduce their adhesion on targets (BARBOSA et al., 2013) and hence change the degree of difficulty of marker removal. Another uncertain factor is the water volume used to wash targets: $20 \mathrm{~mL}$ for coffee leaves (SCUDELER et al., 2004), $40 \mathrm{~mL}$ for citrus leaves (PALLADINI et al., 2005), 20 and $30 \mathrm{~mL}$ in soybean leaves (PINTO et al., 2007 and PRADO et al., 2015, respectively), $50 \mathrm{~mL}$ for artificial target (SASAKI et al., 2013), $100 \mathrm{~mL}$ for tomato leaves (ZAMBIANCO, 2013), and 100 and $150 \mathrm{~mL}$ for peanut and Brachiaria plantaginea leaves (RODRIGUES-COSTA et al., 2011). In addition to this removal volume variability, there are no studies in the literature demonstrating the efficiency of a single washing for a complete removal of a marker (dye).

Thus, the aim of this study was to assess the number of washings and water volumes for brilliant blue dye removal from soybean leaflets and glass slides in fungicide sprayings with and without adjuvants.

\section{MATERIAL AND METHODS}

The experiment was carried out in a completely randomized design arranged in a $3 \times 3 \times 2 \times$ 4 factorial scheme. The factors consisted of tree washings (1st, $2 \mathrm{nd}$, and $3 \mathrm{rd}$ ), tree water volumes $(15,20$, and $30 \mathrm{~mL}$ ), two targets (soybean leaflets and glass slides), and four spray solutions (only the fungicide ProdutorBR ${ }^{\circledR} 0.5 \mathrm{~L} \mathrm{ha}^{-1}$ (spray solution 1) and the fungicide together with the adjuvants Agr'óleo ${ }^{\circledR} 0.5 \% \mathrm{v} \mathrm{v}^{-1}$ (spray solution 2), Nimbus ${ }^{\circledR} 0.5 \% \mathrm{v} \mathrm{v}^{-1}$ (spray solution 3), and Silwet ${ }^{\circledR} 0.04 \% \mathrm{v} \mathrm{v}^{-1}$ (spray solution 4)). All spray solutions contained brilliant blue dye at a concentration of $6 \mathrm{~g} \mathrm{~L}^{-1}$, totaling 72 treatments with four replications.

In each replication, six glass slides $(7.5 \times 2.5 \mathrm{~cm})$ were fixed on metal supports set at the same height as the upper third of two soybean plants at V7 stage (FEHR et al., 1977). In addition, eight leaflets were randomly collected at the upper part of sprayed soybean plants at that stage (Figure 1), totaling 864 glass slides and 1152 washed soybean leaflets.

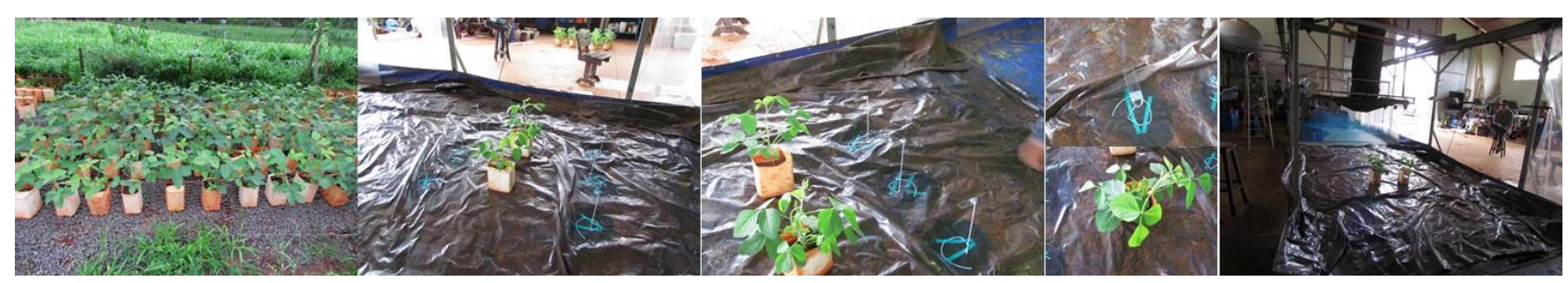

FIGURE 1. Nursery-grown soybean seedlings, distribution of plants throughout the area, glass slide settings with details of the metal supports, and brilliant blue dye spraying onto the targets.

Sprayings were performed using a spraying simulator with $15 \mathrm{~m}$ in length for displacement equipped with a three-meter bar containing four nozzles model TT110015, working at a pressure of $300 \mathrm{kPa}$ (medium droplets), spaced $0.5 \mathrm{~m}$ from each other, and at a height of $0.5 \mathrm{~m}$ from the upper third of plants and glass slides. Bar displacement speed was $1.94 \mathrm{~m} \mathrm{~s}^{-1}$, resulting in an application rate of $100 \mathrm{~L} \mathrm{ha}^{-1}$. The simulator hydraulic system consisted of a manual pressure controller and a three-piston hydraulic pump, powered by a $1.5 \mathrm{~kW}$ electric engine. Climatic conditions at spraying time were an average temperature of $25 \pm 1{ }^{\circ} \mathrm{C}$ and relative humidity of $87 \pm 5 \%$.

After spraying, targets were maintained at ambient condition until full drying (5 minutes). Soybean leaflets and glass slides were conditioned separately in plastic containers $(20 \times 30 \mathrm{~cm})$. Then, depending on the treatment, amounts of 15,20 , or $30 \mathrm{~mL}$ distilled water were added. Afterwards, these plastic containers were shaken for $1 \mathrm{~min}$ with vertical and horizontal movements (1st washing), being repeated for two more times (2nd and 3rd washings) with the same initial water volume corresponding to each treatment volume. The solution resulted from shakings were 
conditioned in another plastic container (100 mL capacity), which was sent for absorbance measurement by spectrophotometry at $630 \mathrm{~nm}$. A linear equation $(\mathrm{y}=\mathrm{b}+\mathrm{ax})$ was calculated to determine the concentration of dye, in $\mathrm{mg} \mathrm{L}^{-1}$, in each solution by a standard curve ( 15 known dye concentrations and their respective absorbance values). After obtaining the concentration values, we determined the amount retained on targets, in $\mu \mathrm{L}$, by using [eq. (1)].

$$
\mathrm{Vi}=[(\mathrm{Cf} \times \mathrm{Vf}) / \mathrm{Ci}] \times 1000
$$

where,

Vi is the volume retained on the target $(\mu \mathrm{L})$,

$\mathrm{Cf}$ is the dye concentration detected by the spectrophotometer from the linear equation $\left(\mathrm{mg} \mathrm{L}^{-1}\right)$,

Vf is the water volume used to wash the sample $(15,20$ or $30 \mathrm{~mL})$, and

$\mathrm{Ci}$ is the dye concentration in the spray solution $\left(6 \mathrm{~g} \mathrm{~L}^{-1}\right)$.

Soybean leaflets were photographed with a digital camera, on a support, with a top view of the target together with a millimeter scale for calibration. Leaf area was determined by using the AreaMed software. Data were converted into retained volume per unit area and submitted to analysis of variance by the F-test and treatment means were compared at a 95\% confidence level $\left(\mathrm{CI}_{95 \%}\right)$.

\section{RESULTS AND DISCUSSION}

A two-way interaction was observed between the number of washings with water volumes, spray solutions, and targets (Table 1). The number of washings interacted with all other factors, being the most relevant factor for brilliant blue dye removal from the targets.

TABLE 1. Analysis of variance of the factors targets, spray solution, volumes, and number of washings for brilliant blue dye removal in agricultural sprayings.

\begin{tabular}{lccccc}
\hline \multicolumn{1}{c}{ Source } & DF & SS & MS & F & p-value \\
\hline Spray solutions (S) & 3 & 0.07 & 0.02 & $2.35^{\text {ns }}$ & 0.0718 \\
Water volumes (V) & 2 & 0.28 & 0.14 & $14.61^{*}$ & 0.0000 \\
Number of washings (W) & 2 & 60.10 & 30.05 & $3090.34^{*}$ & 0.0000 \\
Targets (T) & 1 & 0.62 & 0.62 & $63.72^{*}$ & 0.0000 \\
$\mathrm{~S} \times \mathrm{V}$ & 6 & 0.09 & 0.01 & $1.52^{\mathrm{ns}}$ & 0.1708 \\
$\mathrm{~S} \times \mathrm{W}$ & 6 & 0.20 & 0.03 & $3.49^{*}$ & 0.0021 \\
$\mathrm{~V} \times \mathrm{W}$ & 4 & 0.20 & 0.05 & $5.23^{*}$ & 0.0004 \\
$\mathrm{~S} \times \mathrm{T}$ & 3 & 0.02 & 0.01 & $0.57^{\mathrm{ns}}$ & 0.6344 \\
$\mathrm{~V} \times \mathrm{T}$ & 2 & 0.02 & 0.01 & $0.82^{\mathrm{ns}}$ & 0.4413 \\
$\mathrm{~W} \times \mathrm{T}$ & 2 & 3.38 & 1.69 & $173.92^{*}$ & 0.0000 \\
$\mathrm{~S} \times \mathrm{V} \times \mathrm{W}$ & 12 & 0.08 & 0.01 & $0.71^{\mathrm{ns}}$ & 0.7471 \\
$\mathrm{~S} \times \mathrm{V} \times \mathrm{T}$ & 6 & 0.05 & 0.01 & $0.88^{\mathrm{ns}}$ & 0.5128 \\
$\mathrm{~S} \times \mathrm{W} \times \mathrm{T}$ & 6 & 0.04 & 0.01 & $0.64^{\mathrm{ns}}$ & 0.6958 \\
$\mathrm{~V} \times \mathrm{W} \times \mathrm{T}$ & 4 & 0.04 & 0.01 & $0.90^{\mathrm{ns}}$ & 0.4623 \\
$\mathrm{~S} \times \mathrm{V} \times \mathrm{W} \times \mathrm{T}$ & 12 & 0.02 & 0.00 & $0.13^{\mathrm{ns}}$ & 0.9998 \\
\hline $\mathrm{CV}(\%)$ & \multicolumn{3}{c}{32.75} & & \\
\hline
\end{tabular}

* Significant by the F-test $(\mathrm{P}<0.05)$; ${ }^{\text {ns }}$ Non-significant by the F-test $(\mathrm{P}<0.05)$; DF - Degrees of freedom; SS - Sum of squares; MS Mean of squares; $\mathrm{CV}$ - Coefficient of variation.

With a single washing, a higher removal of brilliant blue dye was observed for glass slides when compared to soybean leaflets. In the second and third washings, an inversion occurred, i.e. the amount of dye removed became higher for soybean leaflets, demonstrating that only one washing was unable to remove partial or totally the dye (Figure 2). 


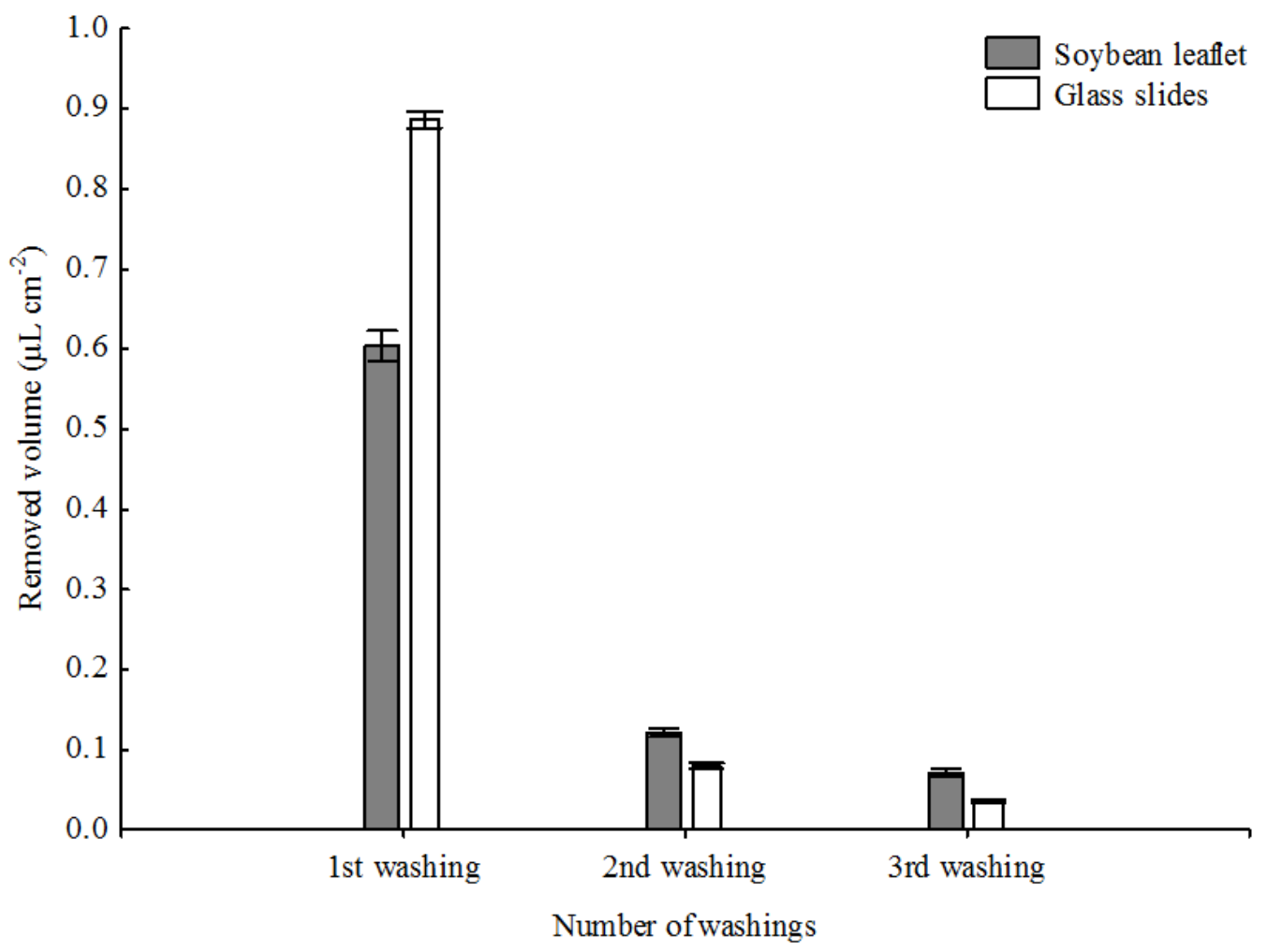

FIGURE 2. Relationship between the number of washings and brilliant blue dye removal from different targets. Bars represent the average removed volume value and the vertical lines indicate a $95 \%$ confidence interval.

Although this inversion has occurred, the sum of dye removed was always higher for the glass slides and for volumes of 20 and $30 \mathrm{~mL}$ (Figure 3), providing a greater dye removal efficiency in the glass slide, being nearly $36 \%$ greater than in soybean leaflets. Thus, glass slides can be considered as suitable targets for spraying deposition removal since the dye was easily removed, as it has distinct features if compared to the natural targets. Glass slides also present a higher percentage of deposition removal, whether compared to leaves of Phaseolus vulgaris and Brachiaria plantaginea (DE CERQUEIRA et al., 2012). Such difference of deposition removal between natural targets and glass slides is due to glass surface hydrophilicity, i.e. having an affinity for water, which facilitates its washing and hence dye removal from its surface, allowing a most reliable comparison between studies (surface pattern used) and reducing the variability among foliar surfaces.

Both targets (natural and glass slide) have advantages and disadvantages. Natural targets should be preferred but their complexity and natural variability have affected dye removal in several studies with greater or lesser magnitude depending on the natural surface, which was also demonstrated in this study. As positive points, natural targets show several morphological traits such as pilosity, cuticle surface, and leaf shape and roughness (REZENDE, 2011) that may also affect dye contact with the surface, leading to losses by retention in foliar tissues (MARCHI et al., 2005). On the other hand, glass slides are uniform and may be placed at pre-established locations, as well as helping to set differences between treatments. Nonetheless, this target is different from field reality. In this sense, the choice between targets (natural and artificial) depends on the circumstances of use and priority of each research.

Although the amount of dye reduced with each washing, there was still removal in the third washing from both targets by using different water volumes (Figure 3 ). The average amount of dye extracted in the last washing corresponded to $5.9 \%$ of that in the first one, for the three water volumes $(15,20$, and $30 \mathrm{~mL})$. The number of washings to be adopted in a study should take into account the expected accuracy as it is unlikely that the dye can be fully extracted from the target although it can get very close to this with successive washings. 
The water volume of $20 \mathrm{~mL}$ was more efficient for dye removal from soybean leaflets and glass slides. Yet, this water volume may have a different performance regarding other targets with distinct characteristics. Conversely, the volume of $15 \mathrm{~mL}$ was inefficient to remove the dye from the surfaces in any of the three washings, showing lower values if compared to the other volumes (20 and $30 \mathrm{~mL}$ ).
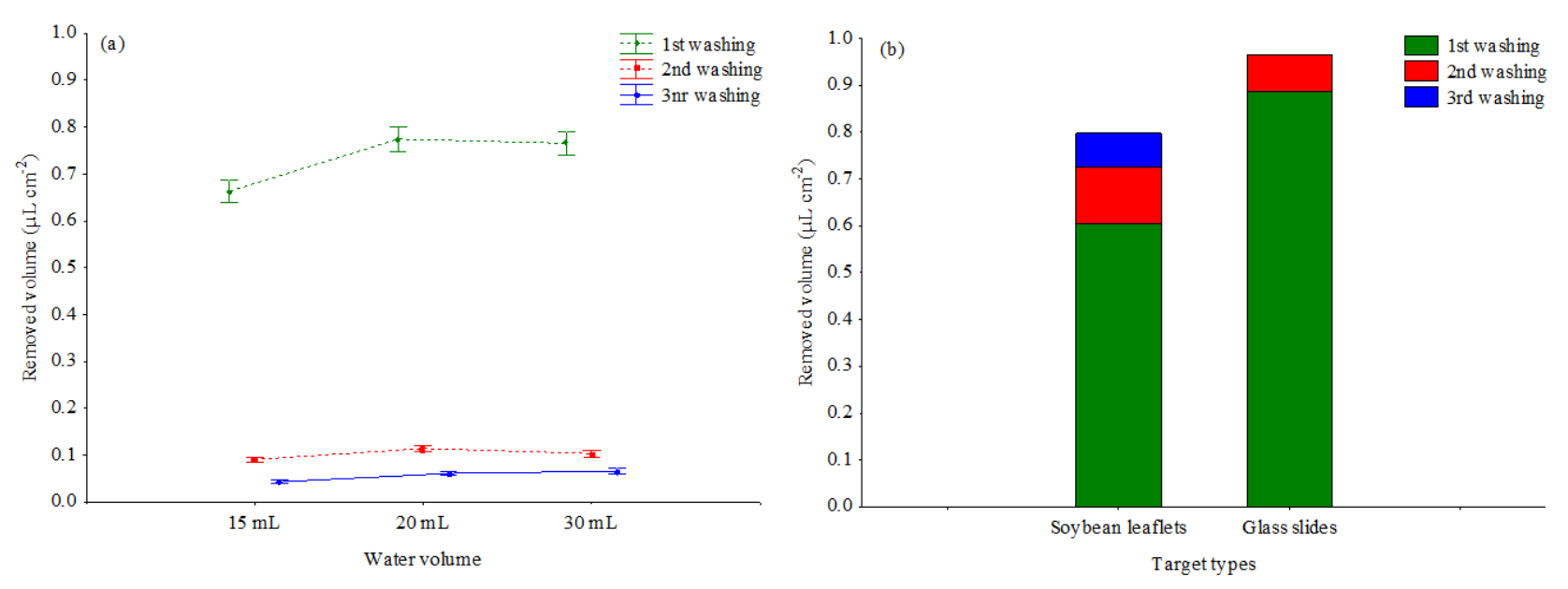

FIGURE 3. Relationship between water volume (a) and target type (b) in the accumulated value of brilliant blue dye removed in three washings.

Furthermore, the type of mixture in spray solution also influenced dye removal. In the first washing, the addition of vegetable oil to fungicide solution hampered the removal process if compared to the mineral oil or surfactant (Figure 4). Studies with spray solution containing plant protection products and adjuvants are important so that the generated droplet spectrum has characteristics close to reality (CHECHETTO \& ANTUNIASSI, 2012). Spray solutions containing solely fungicide presented an intermediate dye removal, i.e. between the maximum and minimum dye removal reached by targets sprayed with fungicide and adjuvants. Higher retention of spray solution was observed for acaricide and vegetable oil when compared to mineral oil in citrus leaves (BARBOSA et al., 2013).

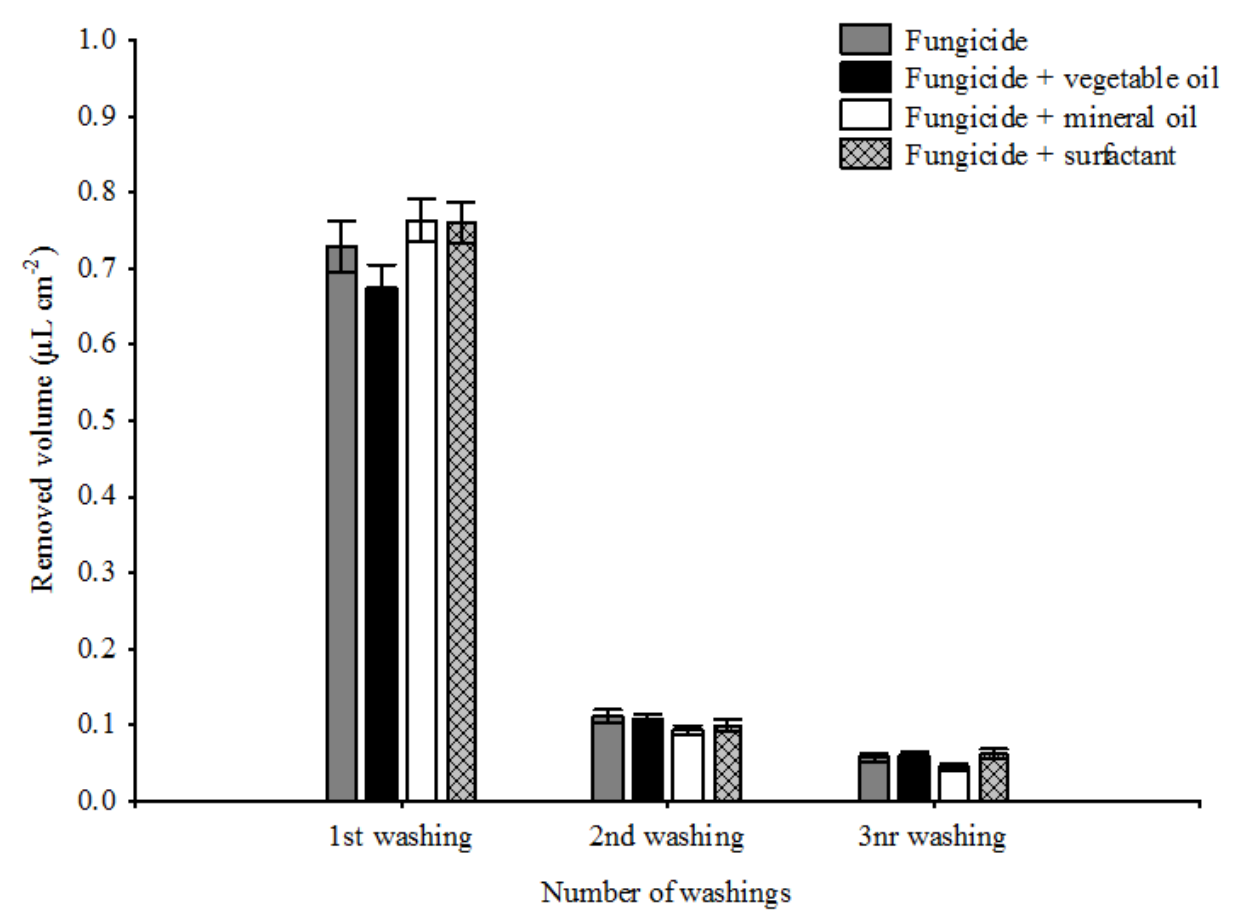

FIGURE 4. Relationship between the number of washings and brilliant blue dye removal in different agricultural spray solutions. Bars represent the average removed volume value and the vertical lines indicate a $95 \%$ confidence interval. 


\section{CONCLUSIONS}

Brilliant blue dye removal is more efficient on glass slides when compared to soybean leaflets.

With a single washing, brilliant blue dye removal was hampered for spray solutions containing fungicide and vegetable oil if compared to fungicide with mineral oil or surfactant.

Only the first washing and a water volume of $15 \mathrm{~mL}$ are no longer sufficient for brilliant blue dye removal from soybean leaflets and glass slides.

\section{REFERENCES}

BARBOSA, G. F.; NAIS, J.; FERREIRA, M. C. Estimativa da área e capacidade de retenção foliar de calda em citros. Bioscience Journal, Uberlândia, v. 29, n. 5, p. 1226-1231, set./out. 2013.

CARVALHO, F. K.; ANTUNIASSI, U. R.; MOTA, A. A. B.; CHECHETTO, R. G.; GANDOLFO, U. D. Adjuvantes de calda no depósito em aplicações aéreas e terrestres. Energia na Agricultura, Botucatu, v. 28, n. 4, p. 215-221, 2013.

CHECHETTO, R. G.; ANTUNIASSI, U. R. Espectro de gotas gerado por diferentes adjuvantes e pontas de pulverização. Revista Energia na Agricultura, v. 27, p. 130-142, 2012.

DE CERQUEIRA, D. T. R.; RAETANO, C. G.; DAL POGETTO, M. H. F. A.; PRADO, E. P.; CHRISTOVAM, R. S.; ALMEIDA COSTA, S. I. Agricultural spray deposit quantification methods. Applied Engineering in Agriculture, St Joseph, v. 28, n. 6, p. 825-831, 2012.

FEHR, W.R.; CAVINESS, C.E. Stages of soybean development. Ames: Iowa State University of Science and Technology, 1977. 11p.

MARCHI, S. R.; MARTINS, D.; COSTA, N. V.; TERRA, M. A.; NEGRISOLI, E. Degradação luminosa e retenção foliar dos corantes Azul Brilhante FCD-1 e Amarelo Tartrasina FCD-5 utilizados como traçadores em pulverizações. Planta Daninha, Viçosa, MG, v. 23, n. 2, p. 287-294. 2005.

MATUO, T. Desenvolvimento de um pulverizador intermitente operado fotoeletricamente para tratamento de pomares de citrus. 1988. 167 f. Tese (Livre Docência) - Universidade Estadual Paulista, Faculdade de Ciências Agrárias e Veterinárias, Jaboticabal, 1988.

PALLADINI, L. A.; RAETANO, C. G.; VELINI, E. D. Choice of tracers for the evaluation of spray deposits. Scientia Agricola, Piracicaba, v. 62, n. 5, p. 440-445, 2005.

PINTO, J. R.; LOECK, A. E.; SOUZA, R. T.; LOUZADA, R. S. Estabilidade à exposição solar dos traçantes azul brilhante e amarelo tartrasina utilizados em estudos de deposição de pulverização. Revista Brasileira de Agrociência, Pelotas, v. 13, n. 1, p. 105-107, 2007.

PRADO, E. P.; CARLOS G. RAETANO, C. G.; DAL POGETTO, M. H. F.; COSTA, S. I. A.; CHRISTOVAM, R. S. Taxa de aplicação e uso de surfactante siliconado na deposição da pulverização e controle da ferrugem da soja. Engenharia Agrícola, Jaboticabal, v. 35, n. 3, p. 514$527,2015$.

REZENDE, D. T. Análise comparativa de métodos para quantificação dos depósitos da pulverização em diferentes alvos. 2011. 67 f. Tese (doutorado) - Universidade Estadual Paulista, Faculdade de Ciências Agrárias e Veterinárias, Jaboticabal, 2011.

RODRIGUES-COSTA, A.C.P.; MARTINS, D.; COSTA, N.V. Uniformidade de deposição de gotas de pulverização em plantas de amendoim e Brachiaria plantaginea. Planta Daninha, Viçosa, MG, v. 29, n. 4, p. 939-951, 2011.

SASAKI, R.S.; MAURI MARTINS TEIXEIRA, M.M.; FERNANDES, H. C.; MONTEIRO, P. M. B.; RODRIGUES, D. E.; ALVARENGA, C. B. Parameters of electrostatic spraying and its influence on the application efficiency. Revista Ceres, Viçosa, MG, v. 60, n. 4, p. 474-479, 2013. 
SCUDELER, F.; RAETANO, C. G.; ARAÚJO. D.; BAUER, F. C. Cobertura da Pulverização e maturação de frutos do cafeeiro com ethephon em diferentes condições operacionais. Bragantia, Campinas, v. 63, n. 1, p. 129-139, 2004.

SILVA, J. E. R.; CUNHA, J. P. A. R. da; NOMELINI, Q. S. S. Deposição de calda em folhas de cafeeiro e perdas para o solo com diferentes taxas de aplicação e pontas de pulverização. Revista Brasileira de Engenharia Agrícola e Ambiental, Campina Grande, v. 18, n. 12, p. 1302-1306. 2014.

ZAIDAN, S. E.; GADANHA JR, C. D.; GANDOLFO, M. A.; PONTELLI, C. O.; MOSQUINI, W. W. Performance of spray nozzles in land applications with high speed. Engenharia Agrícola, Jaboticabal, v. 32, n. 6, p. 1126-1132, 2012.

ZAMBIANCO, E. C. Avaliação da qualidade de pulverização em plantas de tomate utilizando diferentes pontas. 2013. 78f. Dissertação (Mestrado). Escola Superior de Agricultura, Luiz de Queiroz, Universidade de São Paulo, Piracicaba, 2013. 